\title{
Ultrasound-guided interstitial photodynamic therapy for deeply seated pathologies: assessment of outcome
}

\author{
Jonas Osher ${ }^{*}$, Waseem Jerjes, Tahwinder Upile, Zaid Hamdoon, Farai Nhembe, Rishi Bhandari, Sorcha Mackay, \\ Priya Shah, Charles Alexander Mosse, Simon Morley, Colin Hopper
}

From 2nd Scientific Meeting of the Head and Neck Optical Diagnostics Society

San Francisco, CA, USA. 23-24 January 2010

\section{Introduction}

Photodynamic therapy, the fourth oncological intervention modality has proved its successfulness in the management of variety of pathologies involving the human body.

Our aim in this prospective clinical study was to evaluate the outcome following ultrasound-guided iPDT of pathologies involving the head and neck region as well as the upper and lower limbs. Patients' reports on quality of life with clinical and radiological evaluation were the main end point parameters used to assess the outcome.

\section{Materials and methods}

One hundred and ten patients were referred to the UCLH Head and Neck Centre for treatment of various deep-seated pathologies. These included tumours in the head and neck as well as vascular and hamartomatous malformations of the limbs. After multidiscipline discussion, all patients underwent interstitial photodynamic therapy under general anaesthesia, using $0.15 \mathrm{mg} / \mathrm{kg}$ mTHPC as the photosensitising agent. Following treatment, patients were followed-up for a mean of 26 months.

\section{Results}

All 4 patients who presented with visual problems reported improvement after treatment. Also, 17/24 reported improvement of breathing. Improvement of swallowing was reported by $34 / 40$ patients; while speaking improvement was evident in 18/26 patients and 39/ 47 reported reduction in the disfigurement caused by

\footnotetext{
UCL Department of Surgery, University College London Medical School,
} London, UK their pathology. 6/8 patients with impeded limb function reported some degree of improvement.

Clinical assessment showed that more than half of the patients had "good response" to the treatment and a third reported "moderate response". Radiological assessment comparing imaging 6-week post-PDT to the baseline showed moderate response in half of the patients and significant response in 17 patients.

\section{Conclusion}

This study on 95 patients with deep-seated pathologies undergoing interstitial photodynamic therapy provided evidence that PDT can be the fourth modality in the management of tissue disease.

Published: 29 October 2010

doi:10.1186/1758-3284-2-S1-O26

Cite this article as: Osher et al:: Ultrasound-guided interstitial photodynamic therapy for deeply seated pathologies: assessment of outcome. Head \& Neck Oncology 2010 2(Suppl 1):O26.

Submit your next manuscript to BioMed Central and take full advantage of:

- Convenient online submission

- Thorough peer review

- No space constraints or color figure charges

- Immediate publication on acceptance

- Inclusion in PubMed, CAS, Scopus and Google Scholar

- Research which is freely available for redistribution

Submit your manuscript at www.biomedcentral.com/submit
C Biomed Central 